Tourism 2009, 19/1-2

\author{
Aleksander Szwichtenberg \\ Koszalin University of Technology \\ Department of Economics and Management, Division of Tourism \\ aleksz@wp.pl
}

\title{
ACTIVATION OF THE POLISH COASTAL TOURIST RECEPTION REGION USING THE INSTRUMENT OF A PUBLIC-PRIVATE PARTNERSHIP
}

\begin{abstract}
Public-Private Partnership (PPP) is a form of cooperation between the public sector and the private in order to carry out projects or services traditionally supplied by the public sector. This mode of investment is most commonly applied to the creation of technological infrastructure projects. According to the author PPP will allow coastal tourist communes (gminas) to speed up the implementation of the communication infrastructure, and the sport and recreational infrastructure which are presently major barriers to the development of the tourist economy. This is further confirmed by examples presented in this work.
\end{abstract}

Key words: Public-Private Partnership, coastal communes (gminas), accompanying tourist infrastructure.

\section{INTRODUCTION}

The coastal tourist reception region is one of the biggest in Poland in terms of the number of beds (413 000), the number of guests (about $4.4 \mathrm{mln}$ according to the author and $1.9 \mathrm{mln}$ according to the Polish national statistical office!), and the number of over-night stays (in coastal communes $-27.2 \%$ of the entire figure for Poland). On the other hand the area on which the whole of this tourist economy is concentrated, the Baltic coast, often referred to as the Coastal Recreational Zone (Nadmorska Strefa Rekreacyjna - NSR), is particularly small i.e. about $0.75-1 \mathrm{~km}^{2}$, consisting of 79 settlements, mostly of a rural character (SZWICHTENBERG 1991, 2006).

The examined area is characterized by a particularly high level of development as far as the tourist function is concerned. This is indicated by the Baretje-Defert index which for 77 coastal settlements (excluding the Gdańsk-Gdynia conurbation) is 155.5. Therefore many of the 34 coastal communes are among the richest in Poland. Although they have a significant income in their budgets, and are very active in obtaining money from the European Union, they are neither able to satisfy tourists' needs nor those of the communities. The Polish coastal tourist area is not able to compete with those of Western European coasts (Denmark, Germany, France, Belgium) with a similar tourist potential (i.e. the complex of the 3S's - sea, sun, sand).

Considering this, a hypothesis has been put forward in this work stating that the researched coastal communes, in order to become competitive in the European tourist market, should use methods which are widespread around the world for financing projects (investment and non-investment types) and which rely on the private capital. The most appropriate is the Public-Private Partnership (PPP) which encourages the involvement of private enterprise in public projects. In Poland this method is scarcely used in the manner established in other countries. Up until now the idea of such a partnership was still in the realm of academic research, 'experiments' and legislative preparation.

The aim of this work is to:

- set the legal, organizational, economic and psychological barriers to the development of such partnerships in Poland, with particular focus on coastal communes,

- evaluate the social and economic benefits from sport, recreational and other investments on the Polish coast made in the PPP mode,

- identify the new fields of partnership between local governments and private business necessary for an appropriate development of communes with a highly developed tourist function.

In Poland there is very little literature on the subject, especially concerning the application of PPP to the tourist economy: JĘDRZEJCZYK (2004), MARCISZEWSKA \& MIECZNIKOWSKI (2003), MARCISZEWSKA (2007), MIECZNIKOWSKI (2005), SZWICHTENBERG (2007, 2008a-c) and others. These authors mainly tried to 
spread the idea of PPP and show western experience in this respect. The only written account covering the context of the tourist economy and PPP is a monograph entitled 'Public-Private Partnership and tourist economy' written by the author of this article in 2008 (SZWICHTENBERG 2008d).

\section{THE NATURE OF THE PUBLIC-PRIVATE PARTNERSHIP AND THE BARRIERS TO ITS DEVELOPMENT IN POLAND}

The most popular definition of PPP was formulated by the European Commission according to which it is a form of cooperation between the public sector and the private sector in order to provide services usually delivered by the public sector only. Both parties obtain some benefits appropriate to the tasks undertaken. The risk lies with the party that can best control it (Guidelines..., 2003).

Generally it can be stated that there are two options for comprehending PPP, especially in Poland. One 'rigid' - saying that projects in the PPP mode can only be implemented with regard to legislation (symbolically called the 'legalist option') and another, more common one, saying that they are actions in another mode ('liberal option') - SZWICHTENBERG (2008d). Both local government and private enterprise are waiting for an updated act on PPP which the Polish government announced to come in by the end of 20081, as well as other regulations among them changes to concessions for building work (and services). A 'concession' in European terminology and in regulatory documents (e.g. guidelines like green papers) is known as a 'small PPP'.

The main barrier to such development is the slow pace of the legislative process in regulating the implementation of investment and non-investment tasks. This is confirmed by the author's research. Amongst the 34 investigated coastal communes, in as many as $37.7 \%$ no tasks are being undertaken in the PPP mode due to a lack of clear legislation, $18.0 \%$ a lack of good Polish practice, $15.8 \%$ - low awareness and insufficient knowledge, and 9.0\% - a lack of specialists and PPP advisors (SZWICHTENBERG 2008d, p. 47). Several investments in Poland, in the sport and recreations sector, cannot be completed in this mode because of a lack of appropriate legislation. One spectacular example is Water Park - the Sport, Recreation and Rehabilitation Centre in Słupsk (Park Wodny - Centrum Rekreacji Sportowej i Rehabilitacji $w$ Stupsku - PW-CRSiR). investment. The project estimated at $200 \mathrm{mln}$ PLN could not have been implemented in the PPP mode because this investment could not have been placed in the 'Bulletin of
Public Orders'. As a result the town council applied a traditional method, namely it invited tenders for the choice of partner for a capital partnership in order to carry out the investment.

Among the factors inhibiting the development of PPP, a lack of promotional campaigns is another factor worth focusing on. Many authors stress this problem (including KORBUS 2008, PAWLICZ 2008, SZWICHTENBERG 2008c) and other experts and managers (MAKSYMIUK 2008, MALINOWSKI 2008, WALCZAK 2008 and others). A promotional campaign is needed above all in order to show this method properly working. There are many irrational opinions that the private sector gains at the expense of the public, that the preparation of a project in PPP mode takes too long, and finally that the PPP mode brings about a higher risk of corruption. As a matter of fact as far as the two major investments touched upon by the author are concerned (i.e. Saur Neptun Gdańska (SNG) - water and sewage services for the city, and the Haffner Centre $(\mathrm{CH})$ in Sopot - construction of communal and tourist buildings), the negotiation time was fairly long (in the first case it was 30 months and in the second 10 years). It must be mentioned that these investments in PPP mode are unprecedented in Poland, started either at the beginning of the social and economic transformation in Poland (SNG) and in the situation of a complete lack of legal regulation (SNG, $\mathrm{CH}$ ).

\section{THE EVALUATION OF ECONOMIC AND SOCIAL BENEFITS FROM PPP INVESTMENTS IN SPORT, RECREATION AND OTHER AREAS ON THE POLISH COAST}

An attempt was made to estimate the benefits brought by investments in Poland and abroad in the PPP mode as well as those which will be carried out if the coastal communes apply these instruments of economic activation.

The benefits from the application of PPP in the economy are stressed in all academic works, the experts' statements, and above all in any investment plan in this mode. The greatest proof of the benefits obtained from this kind of investment are the statistics confirming the dynamics of the PPP mode elsewhere in the world, especially in Europe. Between 1985-2004 all over the world, excluding Australia, 2096 projects were planned in the field of technical infrastructure worth 887.4 billion dollars, out of which by October 20041121 (450.9 billion dollars) had been completed. Most projects concerned roads $(35 \%)$, railways $(32 \%)$, water $(14 \%)$ and airports $(11 \%)$ - (Synthesis... 2005, p. 4). In Europe, in only 
three years, that is from April 2004 until December 2006, projects worth 95 billion euros were undertaken, out of which those accomplished were worth 17 billion euros (European..., 2008).

The Public-Private Partnership brings benefits for both parties - public and private. WALCZAK \& GRYGIER (2008, p. 5) in reference to the public sector the following benefits are mentioned:

- faster implementation,

- acceleration of the development of the infrastructure,

- a higher level of services,

- an increase in innovation in the provision of services,

- greater operative flexibility etc.

The private sector on the other hand gets stable long term contracts, the opportunity to commercially use innovations, enriching itself by the additional skills and knowledge etc. The most important aspect however are the profits obtained by both sides. In Great Britain, those leading in the incorporation of the PPP mode save between ten and twenty per cent of the investment, obtained both in the process of the investment itself, as well as the current implementation of tasks (index of benefits Value for Money - most frequently from 11 to $17 \%$ ) - KORBUS (2003, p. 10). In the case of social infrastructure and facilities the profits reach as much as 25\% - in France and 50\% in the Netherlands (SOŁTYSIK 2008, p. 5).

For the purpose of this work the author divided the benefits stemming from PPP into macro-, mesoand micro scales (SZWICHTENBERG 2008d, p. 27). In the first it is about the socio-economic benefits for regional development (global, national, regional, settlement), in the second - benefits stemming from the higher efficiency of projects carried out by local communities with the use of private resources (Value for Money) and finally - benefits stemming from the technological-organizational, financial, etc. advantages of PPP projects over those carried out in a traditional way. In order to show the evident benefits from the application of PPP, those three scales were examined with reference to the three projects functioning in the coastal region i.e. SNG in Gdansk, $\mathrm{CH}$ in Sopot and $P W-C R S i R$ in Słupsk (investment at the design phase) - Table 1.

In accordance with the hypothesis in this work the absorption of the PPP idea by the coastal communes is their vital chance to activate the local economy. This method will allow growth in their competitiveness on the European tourist market and these local communes, among the richest in Poland ${ }^{2}$, having achieved great success already in the time of transformation, for example in communal utilities. In fact in that period they eliminated two barriers to development i.e. a lack of drinking water and excessive pollution in the Baltic Sea - their main tourist value (SZWICHTENBERG 2006).

$\mathrm{T}$ a b l e 1. Social and economic benefits created by the implementtation of the three examined projects in the PPP mode

\begin{tabular}{|c|c|}
\hline Examined factor & Effects \\
\hline \multicolumn{2}{|c|}{ I Saur Neptun Gdańsk } \\
\hline Introducing new technologies & $\begin{array}{l}\text { - Monitoring the water } \\
\text { corrosion } \\
\text { - Beneficial changes in } \\
\text { methods of disinfecting } \\
\text { water } \\
\text { - Research into Legionella } \\
\text { bacteria etc. }\end{array}$ \\
\hline $\begin{array}{l}\text { The percentage of drinking water } \\
\text { meeting the requirements of the } \\
\text { European Union between 1992- } \\
2006\end{array}$ & $\begin{array}{l}-1992-8.0 \% \\
-2006-85.9 \%\end{array}$ \\
\hline $\begin{array}{l}\text { The losses of water as a result } \\
\text { of leaks from industrial pipelines } \\
\text { in Gdańsk between 1992-2006 }\end{array}$ & $\begin{array}{l}-1992-25.0 \% \\
-2006-14.0 \%\end{array}$ \\
\hline $\begin{array}{l}\text { Number of breakdowns of the } \\
\text { pipeline network used by SNG } \\
\text { in } 1992 \text { and in } 2006\end{array}$ & $\begin{array}{l}-1992-763 \\
-2006-391\end{array}$ \\
\hline $\begin{array}{l}\text { Positive assessment of water } \\
\text { quality in } 1993 \text { and } 2007 \text { according } \\
\text { to customers }\end{array}$ & $\begin{array}{l}-1993-36.0 \% \\
-2007-68.0 \%\end{array}$ \\
\hline $\begin{array}{l}\text { Positive assessment of SNG } \\
\text { in } 1993 \text { and } 2007 \text { according } \\
\text { to customers of SNG }\end{array}$ & $\begin{array}{l}-1993-11.0 \% \\
-2007-50.0 \%\end{array}$ \\
\hline $\begin{array}{l}\text { The change of attitude of } \\
\text { customers of SNG after } 15 \text { years } \\
\text { on the market between } 1993-2007\end{array}$ & $\begin{array}{l}\text { - Improvement - } 60.0 \% \\
\text { - Deterioration - } 5.0 \%\end{array}$ \\
\hline $\begin{array}{l}\text { Changes in company economic } \\
\text { indices between 1996-2008 }\end{array}$ & $\begin{array}{l}\text { - Income - } 253.6 \% \\
\text { - Profits - } 260.8 \%\end{array}$ \\
\hline \multicolumn{2}{|c|}{ II The Haffner Centre in Sopot } \\
\hline $\begin{array}{l}\text { Building during the implementa- } \\
\text { tion of the project }\end{array}$ & $\begin{array}{l}\text { - A hotel-conference } \\
\text { centre meeting the needs } \\
\text { of a modern sea spa } \\
\text { - Resources needed for the } \\
\text { facilities such as } \\
\text { communication infra- } \\
\text { structure - tunnel, garage } \\
\text { etc., and a building - } \\
2,500 \mathrm{~m}^{2}\end{array}$ \\
\hline
\end{tabular}

III Water Park -

Sport, Recreation and Rehabilitation Centre in Słupsk

\begin{tabular}{|l|l|}
\hline $\begin{array}{l}\text { Projection of income generated } \\
\text { in both models }\end{array}$ & $\begin{array}{l}\text { - Traditional }-8.0 \mathrm{mln} \\
\text { PLN/per year } \\
\end{array}$ \\
& - PPP model $-11.0 \mathrm{mln}$ \\
& PLN/per year \\
\hline Extra money paid by the city & - Traditional $-3.5 \mathrm{mln}$ \\
council for accessibility of the & PLN/per year \\
Centre's services so that it will & - PPP model $-1.9 \mathrm{mln}$ \\
be profitable & PLN/per year
\end{tabular}

S o u r c e: SZWICHTENBERG (2008d).

There are, however, many barriers and limitations left resulting in a lower value of services than at other Baltic or Mediterranean coasts. For example: 
- Most of the communes are mono-functional (tourism) and have only one established tourist product - holiday and recreational, still very imperfect;

- The whole Polish coast, apart from Trójmiasto (Gdańsk, Gdynia and Sopot), has very poor connections with places generating tourism both in Poland and in Europe. Communication outside the coastal settlements is one of the major factors reducing their recreational value;

- The coast is devoid of a sport-recreational infrastructure, a standard feature in other Baltic and Mediterranean coasts;

- European funds, however big and stimulating for the implementation of public tasks, do not allow the building of all necessary facilities for the appropriate functioning of tourism;

- Although the communes enclose in their planing and strategic documents the need for winning external investors, they see no opportunities in PPP;

- Others.

Shortage of finances, and therefore lower competitiveness as compared to non-Polish tourist destinations, is substantial and they are not able to undertake most of their investments without the help of European funds. One of the opportunities to change this situation can be the activation of private capital in the implementation of particular projects.

In the development of the communes in question, it is the perfect time and with particularly advantageous conditions for the beginning of PPP partnership ventures. A very costly water and sewage infrastructure has been created which has stopped the deterioration of the Polish coast and coastal waters. Thanks to a well prepared technical infrastructure the local governments have created advantageous infrastructural and ecological surroundings for the functioning of potential tourist enterprises. Adopting the phraseology used by GOŁEMBSKI (1999), the economic attractiveness of the prospective private investments in this region has greatly increased. On the other hand the communes which build the costly infrastructure see losses from the neglected area of 'para-tourist' investments, crucial for the appropriate functioning of the tourist economy in this area.

All things considered, there is an exceptionally advantageous convergence of events in the coastal region allowing for successful Public-Private Partnership. Firstly private investors realize they are not going to risk the deterioration of the region's attractiveness, secondly there is a wide spectrum for investments profitable both for the public sector as well as for private investors. It can be assumed that the communes which will be first to start up these kind of investments are the most likely to excel in the quality of the offered tourist product. The most successful communes will be those which will concentrate their attention on the implementation of sport-recreational and communication investments, and with promotional campaigns.

\section{IDENTIFICATION OF THE NEW FIELDS OF PARTNERSHIP BETWEEN LOCAL GOVERNMENT AND PRIVATE ENTERPRISE IN TOURIST RECEPTION REGIONS}

The author's research was based on the assumption that the most important investment and non-investment activities on the present stage of development of coastal tourist communes are:

- communication infrastructure,

- sport and recreational infrastructure,

- promotional campaigns.

The communication infrastructure is currently the major barrier to the development of coastal settlements and the accessibility of areas generating tourism, both in Poland and elsewhere in Europe (SZWICHTENBERG 2002). The communication network between the coastal settlements is poor as well. The greatest problem, however, is the lack of rational communicational solutions within the coastal settlements themselves. In most the main stream of traffic runs through the areas of highest recreational value and with the highest concentration of tourists. This decreases the quality of the recreational product (noise, fumes, safety, aesthetics etc.). Almost every coastal town needs a ring road.

The above mentioned problem is also stressed by the authors of planning and strategic documents on all levels for the next 5-10 years, especially at the level of communes and provinces (województwo). These are usually very costly investments. The authors of those plans state that they cannot be implemented relying on traditional sources of financing or aid funds. What is distinctive is that the PPP mode was not taken into account in their implementation either. It is somehow obvious because the strategic plans were created in Poland when this idea was almost unknown and in the period when the impractical PPP legislation had been passed.

Considering road infrastructure it must be noted that it is the most commonly undertaken enterprise in PPP mode in the world. The authorities of the coastal communes will soon acknowledge that the transportation is a field of their local economy that should be involving investments in PPP mode (Table 2).

The present poor state of sport and recreational infrastructure hampers the progress of the tourist economy on the Polish coast and this has a two-fold 
$\mathrm{T}$ a b 1 e 2. Branches of the economy requiring the application of the PPP investment model according to the local governments of the coastal communes

\begin{tabular}{|l|c|}
\hline \multicolumn{1}{|c|}{ Investment or non-investment tasks } & Percentage \\
\hline Sport and recreational infrastructure & 23.5 \\
\hline Transport & 20.7 \\
\hline Social buildings & 10.9 \\
\hline Energy, heating, gas facilities & 9.3 \\
\hline Water supply and sewage & 8.3 \\
\hline Revitalization of cities & 7.8 \\
\hline Protection of the environment & 6.4 \\
\hline Dealing with waste & 4.9 \\
\hline Health service & 2.4 \\
\hline $\begin{array}{l}\text { Others (technological devices, } \\
\text { telecommunications etc.) }\end{array}$ & 5.9 \\
\hline
\end{tabular}

S o u r c e: SZWICHTENBERG (2008d).

significance for the region. On the one hand as one of four necessary forms of tourist activity it defines the attractiveness of tourist reception and the holidayrecreational product in particular. On the other hand its presence allows for the creation of another product i.e. spa tourism. Without this infrastructure the first aspect is very poorly developed and the second impossible to bring to life (this product dominates outside the summer season; sport and recreational facilities are at its core). To sum up, without these facilities the holiday-recreational product is not competitive in Europe, and the spa aspect is restricted to three months in the year.

At present the sport and recreational facilities of the Polish coast are very poorly developed (SZWICHTENBERG 2008d). For example there are 25,200 inhabitants and 11,000 tourists for one open swimming pool (for one covered swimming pool there are 11,000 and 4,800 respectively). As far as covered swimming pools go the situation is much better then the Polish average, where this index is 70,000 inhabitants (Hungary - 2,500, Switzerland $3,100$, Sweden $-5,600)$. It must be stressed that $75.6 \%$ of these pools are in individual hotels and the local inhabitants or tourists who are not accommodated there are not able to use them. Most of the covered pools are very small, functioning as a tool for the owners to run wellness activities. There are only 22.6 $\mathrm{km}$ of promenades for $1.5 \mathrm{mln}$ people $(960000$ local inhabitants, 413000 tourists, and about 100000 one day visitors) that is 60000 people per $\mathrm{km}$ of promenade. Similarly low indices apply to tennis courts, golf courses, aqua parks, marinas, sport halls etc.

Two premises are, in this context, very positive. Firstly this type of investment is important on the European PPP market and is undergoing dynamic development. According to research the speed of the implementation of projects in the field of sport and recreation is much faster than experts WTO experts expected it would be (Public Private..., 2000). According to the European PPP report 2005 the share of this sector in the period of $2004 / 5$ was only $0.75 \%$ of the European PPP market (excluding the road sector $-2 \%$ ), while in the period of 2005/6 3\% and $8 \%$ respectively (European..., 2008). The local authorities also regard it as a very important field for the PPP mode (Table 2).

Another factor limiting the development of tourism on the Polish coast is the lack of a promotional strategy. It was proved that present campaigns in this respect are a waste of resources (SZWICHTENBERG 2006 , p. 158-188). They are incoherent both on the regional level (province województwo - county powiat - commune gmina; commune - commune), and functional (local government - private enterprise). What is most worrying is the lack of professional promotional campaigns for creating an appropriate image of the Polish coast in Europe and beyond.

Many authors stress the benefits stemming from the connection of private and public capital together with appropriate organization of promotional action. Among others PAWLICZ (2008, pg. 43-45), comes to the conclusion that the promotional campaign should be the effect the cooperation of $\mathrm{DMO}^{3}$ and private sector operators. Particular examples of cooperation between the public and private sector on promotional campaigns on a greater scale, also with the participation of the state, are presented by the authors of 'Co-operation and Partnership in Tourism: a Global Perspective' (Co-operation..., 2004, p. 9).

There are two case studies that could be used by province, county and commune governments to promote the Polish coast - i.e. creating an image of the place: 'The Red Sea Riviera' (Egypt) or 'Wonderful Copenhagen as a Place of Meetings' (Denmark). The first can be an example of how to carry out marketing campaigns (mainly concerning promotion) in reference to coastal areas of tourist reception. The second clearly shows local opportunities for creating a tourist product functioning all year round - in this case conference tourism in coastal towns such as Świnoujście, Kołobrzeg and Trójmiasto (GdyniaSopot-Gdańsk). The example of Copenhagen, a Baltic city, speaks for the need for activity in the PPP mode to create conference or congress centres.

Most investments and non-investment actions defined in these three fields, according to research, is an issue of interest among private investors, both Polish and foreign. The key to success in this respect lies solely in the hands of local government, to be exact - in the leaders of those local governments. 


\section{CONCLUSIONS}

The tourist communes, in order to become competitive on the Polish market, and the European in particular, have to decide to carry out investments with the use of private resources. Three important fields of activity for coastal communes have been identified which can be carried out in PPP mode. Those are infrastructure accompanying tourism (mainly sport and recreational), road infrastructure (on two levels firstly improving the accessibility of coastal settlements from other parts of Poland and secondly improving the road network within the 79 rural and urban settlements) and promotional activities.

Coastal communes although, in most cases, among the richest in Poland cannot accomplish such investments from their own income (however high) because of several decades of backwardness in the building of such facilities. The needs of local communities and tourists are growing faster than the increase in income in the communes.

Those local governments which will attempt the 'commune-private enterprise' kind of partnership first are the ones which will stand out very quickly in terms of the quality of the offered tourist product, on the quite monotonous Polish coast. Communes and their leaders are ambivalent towards the idea of PPP and have very little knowledge in this respect. This is because they lack leader-managers who would be able to overcome the present stagnation.

\section{FOOTNOTES}

1 The framework of the new act on Public-Private Partnership of 30.07.2008 has been sent to be agreed between ministers. It must be noted that the first such act was passed in 2005. As a result of complicated procedures no PPP enterprises were carried out based on that particular law.

2 This can be seen by the communes' own income which determines the level of their financial independence. Between 2003-8 profits have increased in the 34 coastal communes by $81.9 \%$ (the average annual increase was $13.7 \%$ ). The average index for those communes is 13 times higher than the average for Poland or 12.5 times higher than in the whole of Zachodniopomorskie province, one of the richest regions in Poland in terms of tourist accommodation (SZWICHTENBERG 2008d).

3 DMO (Destination Marketing Organization) organizations responsible for the marketing of the region (in Poland it is mainly ROTs and LOTs).

\section{BIBLIOGRAPHY}

European PPP Report (2005, 2007), DLA Piper Rudnicki Grey Cary, www.dlapiper.com; 04.11.2008)

Co-operation and Partnership in Tourism: A Global Perspective, WTO, Madrid 2004 Prepared for: Canadian Tourism Commission, World Tourism Organization, World Tourism Organization Business Council, Researched by: KPMG Canada.

GOŁEMBSKI, G. (red.), 1999, Regionalne aspekty rozwoju turystyki, PWN, Warszawa-Poznań.
Guidelines for successful Public-Private Partnerships. European Commission, Directorate General Regional Policy, Brussels, 2003.

JĘDRZEJCZYK, I., 2004, Partnerstwo publiczno-prywatne w realizacji turystycznych projektów inwestycyjnych w regionie, [in:] Kształtowanie jakości produktu turystycznego regionu z zachowaniem rozwoju zrównoważonego, ed. G. Gołembski et al., Instytut Turystyki, Warszawa.

KORBUS, B., 2003, Partnerstwo Publiczno-Prywatne, Urząd Komitetu Integracji Europejskiej, Warszawa.

KORBUS, B., 2008, PPP jako forma realizacji zadań publicznych, Forum $P P P$, no 1(1).

MAKSYMIUK, Z., 2008, Czy potrzebna jest nowelizacja ustawy o PPP? - Forum Dyskusyjne: Forum PPP, no 1(1).

MALINOWSKI, A., 2008, Czy potrzebna jest nowelizacja ustawy ,

MARCISZEWSKA, B., MIECZNIKOWSKI, S., 2003, Partnerstwo publiczno-prywatne a rozwój turystyki w regionie, [in:] Unia Europejska a przyszłość polskiej turystyki, Szkoła Główna Handlowa, Warszawa.

MARCISZEWSKA, B., 2007, Partnerstwo publiczno-prywatne w sektorze turystyki (polskie przykłady zastosowań), [in:] Działania w trybie Partnerstwa Publiczno-Prywatnego na rzecz rozwoju gospodarki turystycznej przy wykorzystaniu środków Unii Europejskiej, ed. A. Szwichtenberg, Strasburg-Koszalin.

MIECZNIKOWSKI, S., 2005, Partnerstwo publiczno-prywatne jako potencjalny instrument rozwoju turystyki w województwie pomorskim, [in:] Polityka turystyczna, ed. A. Panasiuk, Wydawnictwo Uniwersytetu Szczecińskiego, Szczecin-Kopenhaga.

PAWLICZ, A., 2008, Promocja produktu turystycznego - turystyka miejska, Difin, Warszawa.

Public-Private Cooperation. Ehancing. Tourism. Competitiveness. Conseil Professionnel OMT, WTO Business, Consejo Empresarial, WTO, Madrid, Spain October 2000.

SOŁTYSIK, P., 2008, Przykład realizacji PPP z perspektywy sektora prywatnego - Hochtief PPP Solutions GmbH, Materiaty z konferencji pt.: PPP w prawie i praktyce, Lovells, Warszawa (PowerPoint version).

Synthesis of public private partnership. Project for Road, bridges $\mathcal{E}$ tunnels from around the Word - 1985-2004, U.S. Department of Transportation, Federal Highway Administration - Office of Policy, Waszyngton, 2005.

SZWICHTENBERG, A., 1991, Stymulatory $i$ bariery rozwoju funkcji turystycznej w polskiej nadmorskiej strefie rekreacyjnej, Wydawnictwo KONB, Koszalin.

SZWICHTENBERG, A., 2002, Ograniczona dostępność komunikacyjna polskiego Wybrzeża, [in:] Wybrane zagadnienia geografii transportu, ed. J. Wendt, Wydawnictwo US, Szczecin.

SZWICHTENBERG, A., 2006, Gospodarka turystyczna polskiego Wybrzeża, Wydawnictwo Politechniki Koszalińskiej, Koszalin.

SZWICHTENBERG, A., 2007, Istota partnerstwa publiczno-prywatnego (PPP) i możliwości jego realizacji $\mathrm{w}$ gminach nadmorskich $\mathrm{w}$ warunkach obecnie obowiązujących przepisów unijnych, [in:] Działania w trybie Partnerstwa Publiczno-Prywatnego na rzecz rozwoju gospodarki turystycznej przy wykorzystaniu środków Unii Europejskiej, ed. A. Szwichtenberg, Strasburg-Koszalin.

SZWICHTENBERG, A., 2008a, PPP - metoda przyspieszonego rozwoju infrastruktury turystycznej i paraturystycznej na polskim Wybrzeżu, [w:] Problemy Zintegrowanego Zarzadzania Obszarami Przybrzeżnymi w Polsce 'relacje wzajemne morze-ląd', Instytut Nauk o Morzu Uniwersytetu Szczecińskiego, Szczecin 2008 (in print).

SZWICHTENBERG, A., 2008b, PPP - jako najważniejsza droga realizacji inwestycji turystycznych na Wybrzeżu przy wykorzystaniu środków UE, [in:] Fundusze UE dla Gospodarki Morskiej, Gdynia 2008 (in print).

SZWICHTENBERG, A., 2008c, Applications of PPP (Public-Private Partnership) in the tourist economy of Polish coast, 'Wisnik Lwiwskogo Uniwersytetu', Wipusk 24.

SzWICHTENBERG, A., 2008d, Partnerstwo Publiczno-Prywatne a gospodarka turystyczna, Wydawnictwo Politechniki Koszalińskiej, Koszalin.

WALCZAK, M., 2008, PPP korzyści i zagrożenia, Forum PPP, no 1(1). 